Supplement of Geosci. Model Dev., 9, 4405-4437, 2016

http://www.geosci-model-dev.net/9/4405/2016/

doi:10.5194/gmd-9-4405-2016-supplement

(c) Author(s) 2016. CC Attribution 3.0 License.

(c) (i)

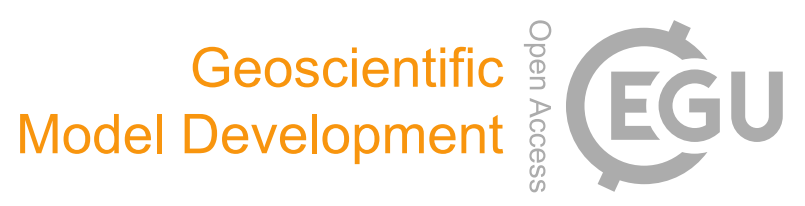

Supplement of

\title{
Terrestrial ecosystem process model Biome-BGCMuSo v4.0: summary of improvements and new modeling possibilities
}

Dóra Hidy et al.

Correspondence to: Dóra Hidy (dori.hidy@gmail.com)

The copyright of individual parts of the supplement might differ from the CC-BY 3.0 licence. 


\section{S1. Parameterization of the case studies for Biome-BGCMuSo v4.0}

Table S1. Complete ecophysiological parameterization of the Biome-BGCMuSo v4.0 model for grass, maize and oak case studies presented in the paper. Superscripts in Reference column refers to the vegetation type (1: grass, 2: maize, 3: oak).

\begin{tabular}{|c|c|c|c|c|}
\hline \multirow[b]{2}{*}{ Parameter name } & \multicolumn{3}{|c|}{ Parameter values } & \multirow[t]{2}{*}{ References/remarks } \\
\hline & $\begin{array}{l}\text { grass } \\
(1)\end{array}$ & $\begin{array}{l}\text { maize } \\
(2)\end{array}$ & $\begin{array}{l}\text { oak } \\
(3)\end{array}$ & \\
\hline $\begin{array}{l}\text { transfer growth period as fraction } \\
\text { of growing season }\end{array}$ & 1 & 1 & 0.3 & model default ${ }^{1,2}$, Golinkoff $(2013)^{3}$ \\
\hline $\begin{array}{l}\text { litterfall as fraction of growing } \\
\text { season }\end{array}$ & 1 & 1 & 0.3 & model default ${ }^{1,2}$, Pietsch et al. $(2005)^{3}$ \\
\hline base temperature & 3.6 & 8 & 5 & Fodor et al. $(2014)^{2,}$, field observation ${ }^{1,3}$ \\
\hline $\begin{array}{l}\text { growing degree day for start of } \\
\text { yield allocation }\end{array}$ & N/A & 825 & 1000 & $\begin{array}{l}\text { based on Fodor et al. }(2014)^{2,} \text {, field } \\
\text { observation }^{3}\end{array}$ \\
\hline $\begin{array}{l}\text { growing degree day of start } \\
\text { genetically programmed } \\
\text { senescence }\end{array}$ & N/A & 1680 & 2350 & 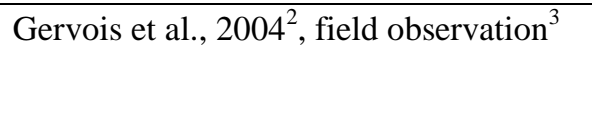 \\
\hline $\begin{array}{l}\text { annual leaf and fine root turnover } \\
\text { fract. }\end{array}$ & 1 & 1 & 1 & $\begin{array}{l}\text { White et al. }(2000)^{1,2} \text {, Pietsch et al. } \\
(2005)^{3}\end{array}$ \\
\hline $\begin{array}{l}\text { annual live wood turnover } \\
\text { fraction }\end{array}$ & N/A & N/A & 0.7 & Pietsch et al. $(2005)^{3}$ \\
\hline $\begin{array}{l}\text { annual whole-plant mortality } \\
\text { fraction }\end{array}$ & 0.05 & 0.02 & 0.02 & White et al. $(2000)^{1,2}$, field observation ${ }^{3}$ \\
\hline annual fire mortality fraction & 0 & 0 & 0 & no fire was observed in the study period \\
\hline new fine root $C$ : new leaf $C$ & 1 & 1.02 & 0.95 & $\begin{array}{l}\text { White et al. }(2000)^{1} \text {, Oleson et al. } \\
(2013)^{2} \text {, Ostrogović }(2013)^{3}\end{array}$ \\
\hline new fruit $C$ : new leaf $C$ & 0 & 0.56 & 0.14 & $\begin{array}{l}\text { White et al. }(2000)^{1} \text {, Oleson et al. } \\
(2013)^{2} \text {, Ostrogović }(2013)^{3}\end{array}$ \\
\hline new softstem $C$ : new leaf $C$ & 0.5 & 2.05 & N/A & $\begin{array}{l}\text { White et al. }(2000)^{1} \text {, Oleson et al. } \\
(2013)^{2}\end{array}$ \\
\hline new woody stem $\mathrm{C}$ : new leaf $\mathrm{C}$ & N/A & N/A & 1.42 & Ostrogović $(2013)^{3}$ \\
\hline $\begin{array}{l}\text { new live wood } \mathrm{C}: \text { new total } \\
\text { wood } \mathrm{C}\end{array}$ & N/A & N/A & 0.16 & Pietsch et al. $(2005)^{3}$ \\
\hline new coarse $\operatorname{root} C$ : new stem $C$ & N/A & N/A & 0.26 & Pietsch et al. $(2005)^{3}$ \\
\hline current growth proportion & 0.4 & 1 & 0.5 & $\begin{array}{l}\text { based on Hidy et al. }(2012)^{1} \text {, Pietsch et } \\
\text { al. }(2005)^{3} \text {, see main text for explanation } \\
\text { on maize parameter }\end{array}$ \\
\hline$C: N$ of leaves & 25 & 14.3 & 24.5 & $\begin{array}{l}\text { White et al. }(2000)^{1}, \text { adjusted } \\
\text { parameter }^{2} \text {, Seletković }(2003)^{3}\end{array}$ \\
\hline$C: N$ of leaf litter & 45 & 65 & 47.5 & $\begin{array}{l}\text { White et al. }(2000)^{1} \text {, Oleson et al. } \\
(2014)^{2} \text {, laboratory analysis }{ }^{3}\end{array}$ \\
\hline $\mathrm{C}: \mathrm{N}$ of fine roots & 50 & 42 & 43 & $\begin{array}{l}\text { White et al. }(2000)^{1} \text {, Oleson et al. } \\
(2014)^{2} \text {, Gordon and Jackson }(2000) \text { and } \\
\text { Zadworny et al. }(2015)^{3}\end{array}$ \\
\hline $\mathrm{C}: \mathrm{N}$ of fruit & 25 & 50 & 0.33 & $\begin{array}{l}\text { White et al. }(2000)^{1} \text {, Oleson et al. } \\
(2014)^{2} \text {, Toscano and Cimino }(2013)^{3}\end{array}$ \\
\hline $\mathrm{C}: \mathrm{N}$ of softstem & 25 & 85 & N/A & $\begin{array}{l}\text { same as the } \mathrm{C}: \mathrm{N} \text { ratio of leaves }{ }^{1} \text {, Oleson } \\
\text { et al. }(2014)^{2} \text {, }\end{array}$ \\
\hline $\mathrm{C}: \mathrm{N}$ of live wood & N/A & N/A & 73.5 & Pietsch et al. $(2005)^{3}$ \\
\hline C:N of dead wood & N/A & N/A & 451 & Pietsch et al. $(2005)^{3}$ \\
\hline
\end{tabular}




\begin{tabular}{|c|c|c|c|c|}
\hline leaf litter labile proportion & 0.68 & 0.68 & 0.2 & $\begin{array}{l}\text { White et al. }(2000)^{1,2} \text {, Pietsch et al. } \\
(2005)^{3}\end{array}$ \\
\hline leaf litter cellulose proportion & 0.23 & 0.23 & 0.56 & $\begin{array}{l}\text { White et al. }(2000)^{1,2} \text {, Pietsch et al. } \\
(2005)^{3}\end{array}$ \\
\hline fine root litter labile proportion & 0.34 & 0.34 & 0.34 & $\begin{array}{l}\text { White et al. }(2000)^{1,2} \text {, Pietsch et al. } \\
(2005)^{3}\end{array}$ \\
\hline $\begin{array}{l}\text { fine root litter cellulose } \\
\text { proportion }\end{array}$ & 0.44 & 0.44 & 0.44 & $\begin{array}{l}\text { White et al. }(2000)^{1,2} \text {, Pietsch et al. } \\
(2005)^{3}\end{array}$ \\
\hline fruit litter labile proportion & 0.68 & 0.68 & 0.3 & $\begin{array}{l}\text { same as labile proportion of leaves }{ }^{1,2} \text {, } \\
\text { Toscano and Cimino }(2013)^{3}\end{array}$ \\
\hline fruit litter cellulose proportion & 0.23 & 0.23 & 0.29 & $\begin{array}{l}\text { same as labile proportion of leaves } \\
{\text { Toscano and Cimino }(2013)^{3}}^{1,2} \text {, }\end{array}$ \\
\hline softstem litter labile proportion & 0.68 & 0.68 & N/A & same as labile proportion of leaves ${ }^{1,2}$ \\
\hline $\begin{array}{l}\text { softstem litter cellulose } \\
\text { proportion }\end{array}$ & 0.23 & 0.23 & N/A & same as labile proportion of leaves ${ }^{1,2}$ \\
\hline dead wood cellulose proportion & N/A & N/A & 0.75 & Pietsch et al. $(2005)^{3}$ \\
\hline $\begin{array}{l}\text { canopy water interception } \\
\text { coefficient }\end{array}$ & 0.01 & 0.01 & 0.038 & $\begin{array}{l}\text { adjusted parameter, } \\
(2005)^{3}\end{array}$ \\
\hline $\begin{array}{l}\text { canopy light extinction } \\
\text { coefficient }\end{array}$ & 0.4 & 0.6 & 0.54 & $\begin{array}{l}\begin{array}{l}\text { adjusted } \\
(2005)^{3}\end{array} \\
\text { parameter }{ }^{1,2} \text {, Pietsch et al. }\end{array}$ \\
\hline $\begin{array}{l}\text { all-sided to projected leaf area } \\
\text { ratio }\end{array}$ & 2 & 2 & 2 & White et al. $(2000)^{1,2,3}$ \\
\hline canopy average specific leaf area & 49 & 43.3 & 34.5 & $\begin{array}{l}\text { White et al. }(2000)^{1} \text {, based on Oleson et } \\
\text { al. }(2014)^{2} \text {, Pietsch et al. }(2005)^{3}\end{array}$ \\
\hline $\begin{array}{l}\text { ratio of shaded specific leaf } \\
\text { area:sunlit specific leaf area }\end{array}$ & 2 & 2 & 2 & White et al. $(2000)^{1,2,3}$ \\
\hline fraction of leaf $\mathrm{N}$ in Rubisco & 0.3 & 0.143 & 0.088 & $\begin{array}{l}\text { proposed value }{ }^{1} \text {, calculated from canopy } \\
\text { average specific leaf area, leaf C:N and } \\
\mathrm{V}_{\text {cmax }} \text { where the latter was defined by } \\
\text { Oleson et al. }(2014)^{2} \text {, Pietsch et al. } \\
(2005)^{3}\end{array}$ \\
\hline $\begin{array}{l}\text { fraction of leaf } \mathrm{N} \text { in } \mathrm{PeP} \\
\text { carboxylase }\end{array}$ & N/A & 0.03 & N/A & Di Vittorio et al. $(2010)^{2}$ \\
\hline maximum stomatal conductance & 0.0032 & 0.012 & 0.0024 & $\begin{array}{l}\text { proposed value }{ }^{1} \text {, Oleson et al. }(2014)^{2} \text {, } \\
\text { Pietsch et al. }(2005)^{3}\end{array}$ \\
\hline cuticular conductance & 0.00006 & 0.00006 & 0.00006 & White et al. $(2000)^{1,2,3}$ \\
\hline boundary layer conductance & 0.04 & 0.04 & 0.005 & $\begin{array}{l}\text { White et al. }(2000)^{1,2} \text {, Pietsch et al. } \\
(2005)^{3}\end{array}$ \\
\hline $\begin{array}{l}\text { relative soil water content } \\
\text { limitation } 1 \text { (proportion to field } \\
\text { capacity value) }\end{array}$ & 1 & 1 & 0.9 & proposed value (this study) $)^{1,2,3}$ \\
\hline $\begin{array}{l}\text { relative soil water content } \\
\text { limitation } 2 \text { (proportion to } \\
\text { saturation capacity value) }\end{array}$ & 0.99 & 0.99 & 0.985 & proposed value (this study) ${ }^{1,2,3}$ \\
\hline $\begin{array}{l}\text { vapor pressure deficit: start of } \\
\text { conductance reduction }\end{array}$ & 1000 & 1000 & 200 & $\begin{array}{l}\text { White et al. }(2000)^{1,2} \text {, Pietsch et al. } \\
(2005)^{3}\end{array}$ \\
\hline $\begin{array}{l}\text { vapor pressure deficit: complete } \\
\text { conductance reduction }\end{array}$ & 4600 & 5000 & 2550 & $\begin{array}{l}\text { White et al. }(2000)^{1,2} \text {, Pietsch et al. } \\
(2005)^{3}\end{array}$ \\
\hline $\begin{array}{l}\text { senescence mortality coefficient } \\
\text { of aboveground plant material }\end{array}$ & 0.05 & 0.05 & 0.01 & proposed value (this study) $)^{1,2,3}$ \\
\hline $\begin{array}{l}\text { senescence mortality coefficient } \\
\text { of belowground plant material }\end{array}$ & 0.01 & 0.01 & 0.01 & proposed value (this study) ${ }^{1,2,3}$ \\
\hline $\begin{array}{l}\text { genetically programmed } \\
\text { senescence mortality coefficient } \\
\text { of leaf }\end{array}$ & 0 & 0.1 & 0.025 & proposed value (this study) $)^{1,2,3}$ \\
\hline
\end{tabular}




\begin{tabular}{|c|c|c|c|c|}
\hline $\begin{array}{l}\text { turnover rate of wilted standing } \\
\text { biomass to litter }\end{array}$ & 0.006 & 0.001 & 0.01 & proposed value (this study) ${ }^{1,2,3}$ \\
\hline $\begin{array}{l}\text { turnover rate of cut-down non- } \\
\text { woody biomass to litter }\end{array}$ & 0.003 & 0.01 & 0.05 & proposed value (this study) $)^{1,2,3}$ \\
\hline $\mathrm{N}$ denitrification proportion & 0.01 & 0.01 & 0.01 & original model setting $^{1,2,3}$ \\
\hline $\begin{array}{l}\text { bulk } \mathrm{N} \text { denitrification proportion, } \\
\text { wet case }\end{array}$ & 0.0068 & 0.068 & 0.02 & proposed value (this study) ${ }^{1,2,3}$ \\
\hline $\begin{array}{l}\text { bulk } \mathrm{N} \text { denitrification proportion, } \\
\text { dry case }\end{array}$ & 0.0003 & 0.01 & 0.01 & proposed value (this study) ${ }^{1,2,3}$ \\
\hline mobile N proprotion (leaching) & 0.1 & 0.1 & 0.1 & Trusilova et al. $(2009)^{1,2,3}$ \\
\hline $\begin{array}{l}\text { symbiotic+asymbiotic fixation of } \\
\mathrm{N}\end{array}$ & 0.0007 & 0.0005 & 0.0036 & $\begin{array}{l}\text { proposed value (this study) }{ }^{1,2} \text {, Binkley et } \\
\text { al. (1994) and Marjanović et al. (2011) }\end{array}$ \\
\hline $\begin{array}{l}\text { ratio of storage and actual pool } \\
\text { mortalitay due to management }\end{array}$ & 0.1 & 0.1 & 0.9 & proposed value (this study) $)^{1,2,3}$ \\
\hline $\begin{array}{l}\text { critical value of soilstress } \\
\text { coefficient }\end{array}$ & 0.54 & 0.4 & 0.5 & proposed value (this study) $)^{1,2,3}$ \\
\hline critical number of stress days & 60 & 60 & 90 & proposed value (this study) $)^{1,2,3}$ \\
\hline maximum depth of rooting zone & 0.7 & 0.8 & 1 & $\begin{array}{l}\text { based on Hidy et al. }(2012)^{1} \text {, proposed } \\
\text { value (this study) })^{2} \text {, personal assasment }\end{array}$ \\
\hline root distribution parameter & 1.85 & 3.67 & 3.67 & $\begin{array}{l}\text { adjusted parameter after Jarvis et al. } \\
(1989)^{1,2,3}\end{array}$ \\
\hline maturity coefficient & 0.5 & 0.5 & 0.5 & proposed value (this study) $)^{1,2,3}$ \\
\hline $\begin{array}{l}\text { growth respiration per unit of } \mathrm{C} \\
\text { grown }\end{array}$ & 0.3 & 0.3 & 0.3 & $\begin{array}{l}\text { original model setting (defined by the } \\
\text { source code) }\end{array}$ \\
\hline $\begin{array}{l}\text { maintenance respiration in } \\
\mathrm{kgC/day} \text { per } \mathrm{kg} \text { of tissue } \mathrm{N}\end{array}$ & 0.218 & 0.218 & 0.4 & $\begin{array}{l}\text { original model setting (defined by the } \\
\text { source code })^{1,2} \text {, Cannell and Thornley } \\
(2000)^{3}\end{array}$ \\
\hline
\end{tabular}




\section{S2. Additional case studies for Bugac}

\section{S2.1 Case study on the effect of long lasting drought on plant state}

First we present a case study to demonstrate the effect of soil moisture stress on plant tissue senescence and recuperation (re-greening).

The sandy grassland site at Bugac is prone to drought, and due to the climate of the Hungarian Great Planes grass senescence occurs in almost each summer, which is followed by regrowth in late summer/early autumn.

Here we examine the measured precipitation data, the simulated soil water content (SWC) data, the soil moisture stress index (SMSI), the simulated carbon content of leaf (leafC) and standing dead biomass (STDBC) and the measured and simulated gross primary production (GPP) data from 1 May, 2009, to 31 October, 2009, at Bugac (Fig. S1).

The simulation was initiated with prescribed grazing from day of year 156 to 202 and from 262 to 311 , with average stocking rate 0.69 and $1.15 \mathrm{LSU} \mathrm{ha}^{-1}$, respectively.

There was no significant rainfall (i.e. precipitation larger than $10 \mathrm{~mm}$ ) until 22 May (first vertical grey dashed line; Fig. S1). As a result, the soil became drier and drier gradually, stomatal conductance was limited by the depleted SWC (SMSI was less than 1; Fig. S1c), and therefore GPP was low (Fig. 6a in the main paper). Parallel to stomatal limitation leaf senescence occurred (SMSI decreased below the critical value; this is indicated by the horizontal grey dotted line on Fig. S1c), therefore the leafC started to be allocated to STDB until the end 22 May (Fig. S1d). A significant precipitation event occurred on 4 August (second grey dashed line). Between the two large precipitation events the stomatal conductance was limited (SMSI was less than 1) but SMSI was above the critical value (Table S1) therefore the carbon allocation to STDB was zero, and the STDB started to decrease (reallocation to litter pool). After the second large precipitation event, the SMSI value increased and approached 1, the stomatal limitation became small, so the leafC and GPP started to increase. This consecutive drought and recuperation periods are frequent at Bugac (Nagy et al., 2010). Considering the temporal evolution of GPP fluxes the course was realistic and it was consistent with the measured data. 


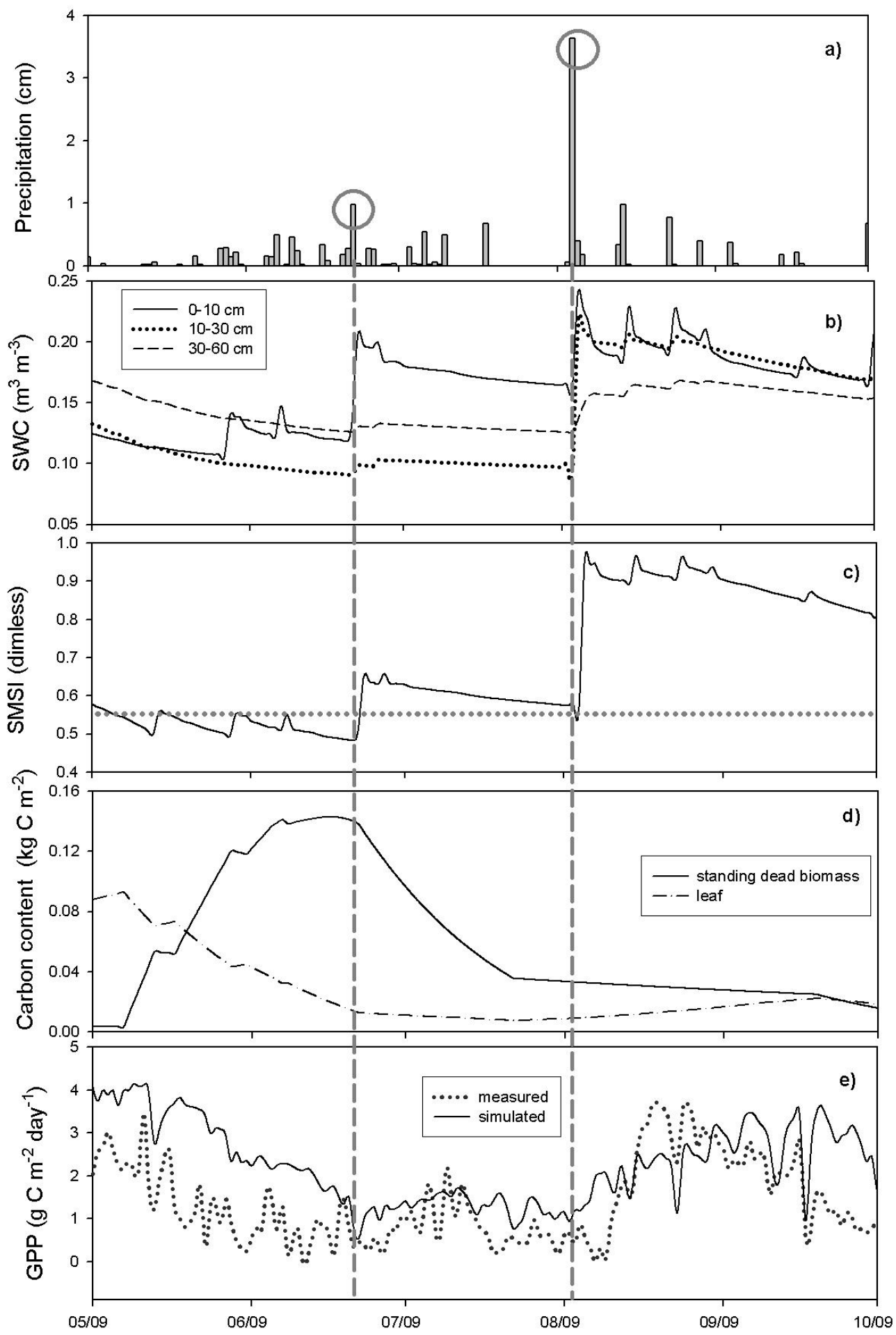

Figure S1: Measured and simulated variables representing the soil stress effect on productivity and leaf senescence at Bugac between 09/05/2009 and 10/09/2009. a) observed precipitation; b) simulated soil water content in the different soil layers (solid line: $0-10 \mathrm{~cm}$, dashed line: 10-30 cm, dotted line: 30-60 cm); c) soil moisture stress index, d) simulated carbon content of leaf (dashed line) and standing dead biomass (solid line); e) measured (dotted line) and simulated (solid line) gross primary production. Vertical grey dashed lines represent the dates of larger precipitation events (also marked by circles in a)). Dotted line in c) represents critical SMSI. 


\section{S2.2 Case studies showing the effect of senescence on plant processes and carbon balance}

In this case study two simulations are compared using Biome-BGCMuSo v4.0 for the Bugac grassland. The first is without senescence effect (no senescence, which means that the 'senescence mortality coefficient of aboveground plant material' parameter is zero) while the second is with senescence effect (the senescence mortality coefficients are set to the proposed values; see Table $\mathrm{S} 1$ ).

Fig. S2 shows that senescence alters soil water content and thus SMSI, due to changes in leaf area index which alters canopy water interception. Standing dead biomass pool is empty in the no-senescence case as this pool is specifically defined to contain wilted leaves that are not yet part of the litter pool. Due to senescence simulation the assimilation process is limited, part of the plant material turns into the litter pool, therefore the overestimation of GPP decreased relative to observations (root mean squared error decreases from 4.6 to $1.6 \mathrm{gC} \mathrm{m}^{-2}$ day $^{-1}$ ), the correlation between measured and simulated GPP data became higher using senescence simulation $\left(\mathrm{R}^{2}=0.66\right)$ then without senescence simulation $\left(\mathrm{R}^{2}=0.38\right)$. 

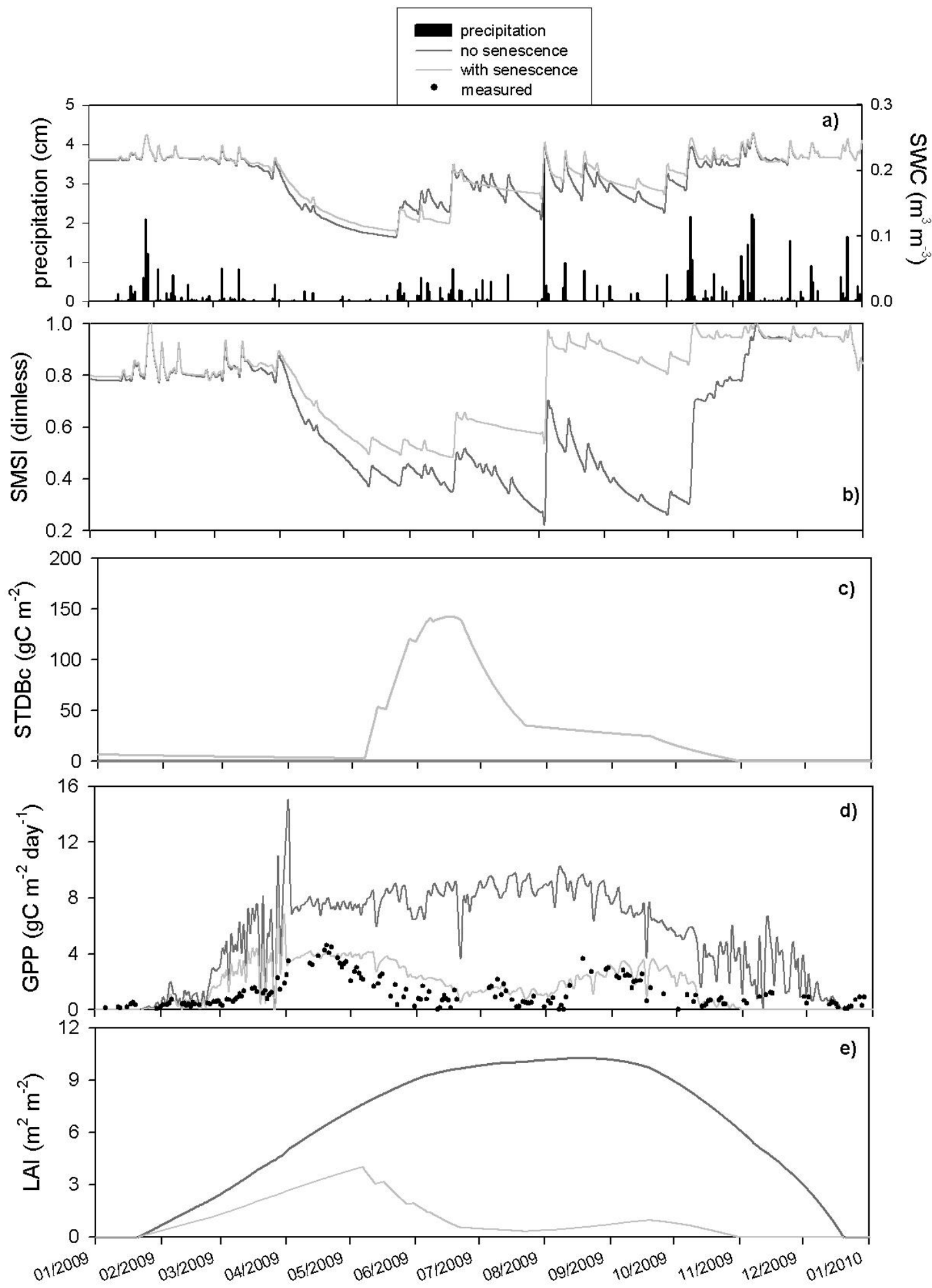

Figure S2: Measured (black dots) and simulated (dark grey lines: no senescence; light grey lines: with senescence) variables representing the soil stress effect at Bugac in 2009. a) measured precipitation (black column) and SWC in the top soil layer (grey lines); b) soil moisture stress index, c) simulated carbon content of standing dead biomass (STDBc); d) measured (dotted line) and simulated (solid line) gross primary production, and e) simulated leaf area index. 


\section{S2.3 Case studies showing the effect of grazing}

Bugac belongs to the Kiskunság National Park and has been under extensive grazing by a Hungarian grey cattle herd in the last 20 years. We present one-year simulation for Bugac to demonstrate the effect of grazing on carbon fluxes, availability of mineralized nitrogen in the root zone, and leaf area index. Stocking density was 0.23-0.58 animal ha ${ }^{-1}$ during the 220day-long grazing period between 2004 and 2012.

Fig. S3 shows that that grazing alters the carbon fluxes due to removal of plant material (defoliation) in the grazing period and the increasing soil mineral nitrogen content (SMINN) of soil. This latter increase is likely the consequence of manure input due to animal excrement. 

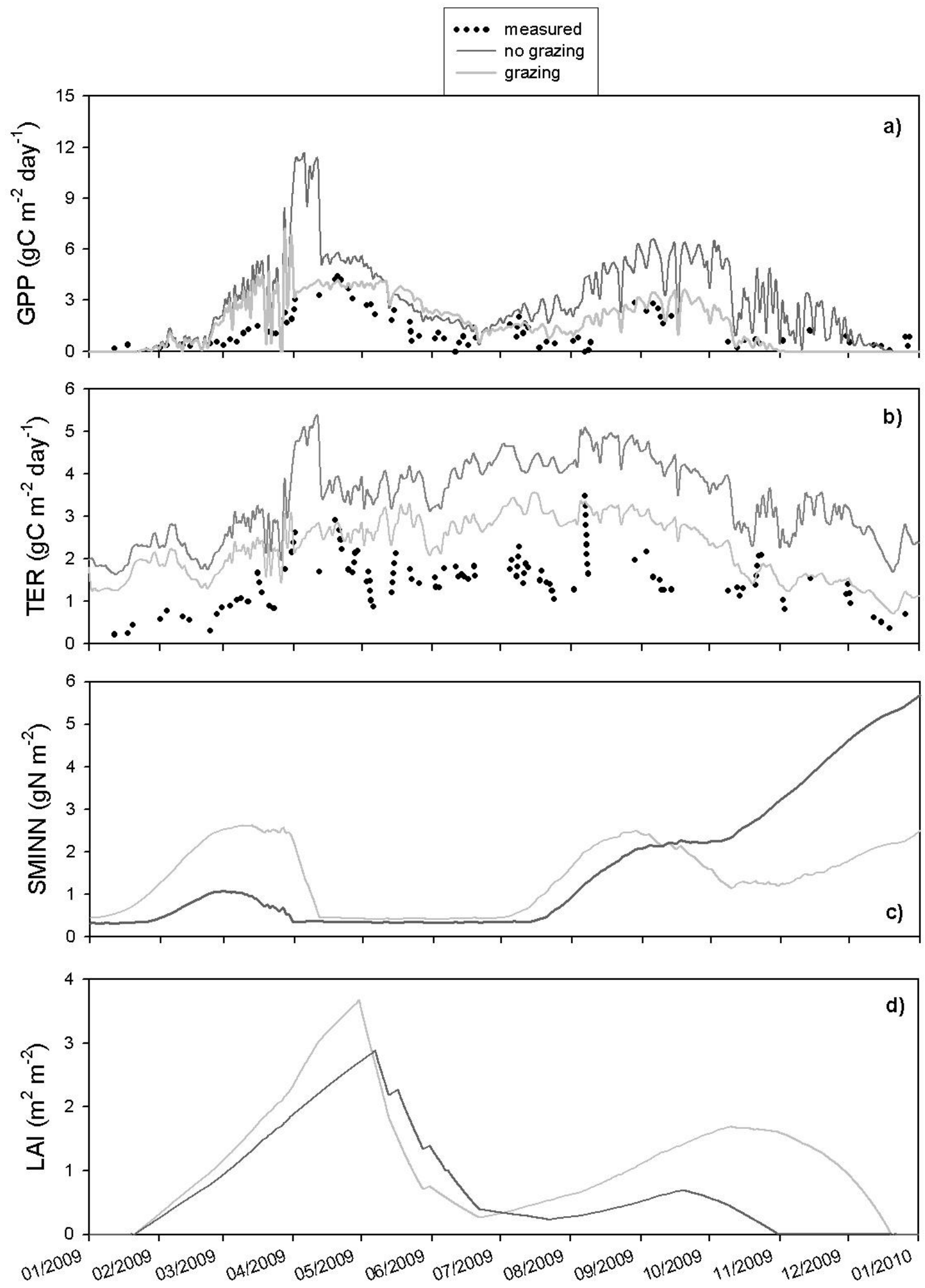

Figure S3: Measured (black dots) and simulated (dark grey lines: no grazing; light grey lines: with grazing) variables representing the grazing effect regarding Bugac in 2009. a) gross primary production; b) total ecosystem respiration; c) mineralized nitrogen content of the soil; d) leaf area index. 


\section{S3. Additional case studies for Mead}

\section{S3.1 Case study on the effect of irrigation and fertilization}

The measurement site at Mead1 is equipped with center-pivot irrigation system and the soil is fertilized, which processes assist in the growing of agricultural crops.

Simulation was initialized with grassland parameterization in the spinup phase by re-using the observed meteorology. The model was initialized with annually varied planting (planting day varied between day of year (doy) 119 and 134, the quantity of seed between 24 and $29 \mathrm{~kg}$ seed $\mathrm{ha}^{-1}$ ), harvesting (harvesting day varied between doy 276 and 316, the carbon content of soft stem after harvest was set to $0.01 \mathrm{~kg} \mathrm{C} \mathrm{m}^{-2}$ ), fertilization (fertilization day varied between doy 103 and 134; the amount of nitrogen from fertilization varied between 113 and $179 \mathrm{~kg} \mathrm{~N} \mathrm{ha}^{-1} \mathrm{day}^{-1}$ ) and ploughing (ploughing day varied between doy 298 and 316). The effect of fertilization and irrigation was examined by comparing simulated net ecosystem exchange (NEE), SMSI, crop yield (fruitC) and LAI with fertilization and irrigation, and without fertilization and without irrigation (Fig. S4). The figure shows that without irrigation the soil stress is higher (SMSI is lower), therefore carbon assimilation is limited, and the carbon content of the fruit (and parallel the leaf area index) is lower. The effects of fertilization on carbon assimilation and carbon stocks are similar but not due to the decease of soil water limitation but due to the higher soil mineral nitrogen content of which absence is an important limiting factor of plant processes. 

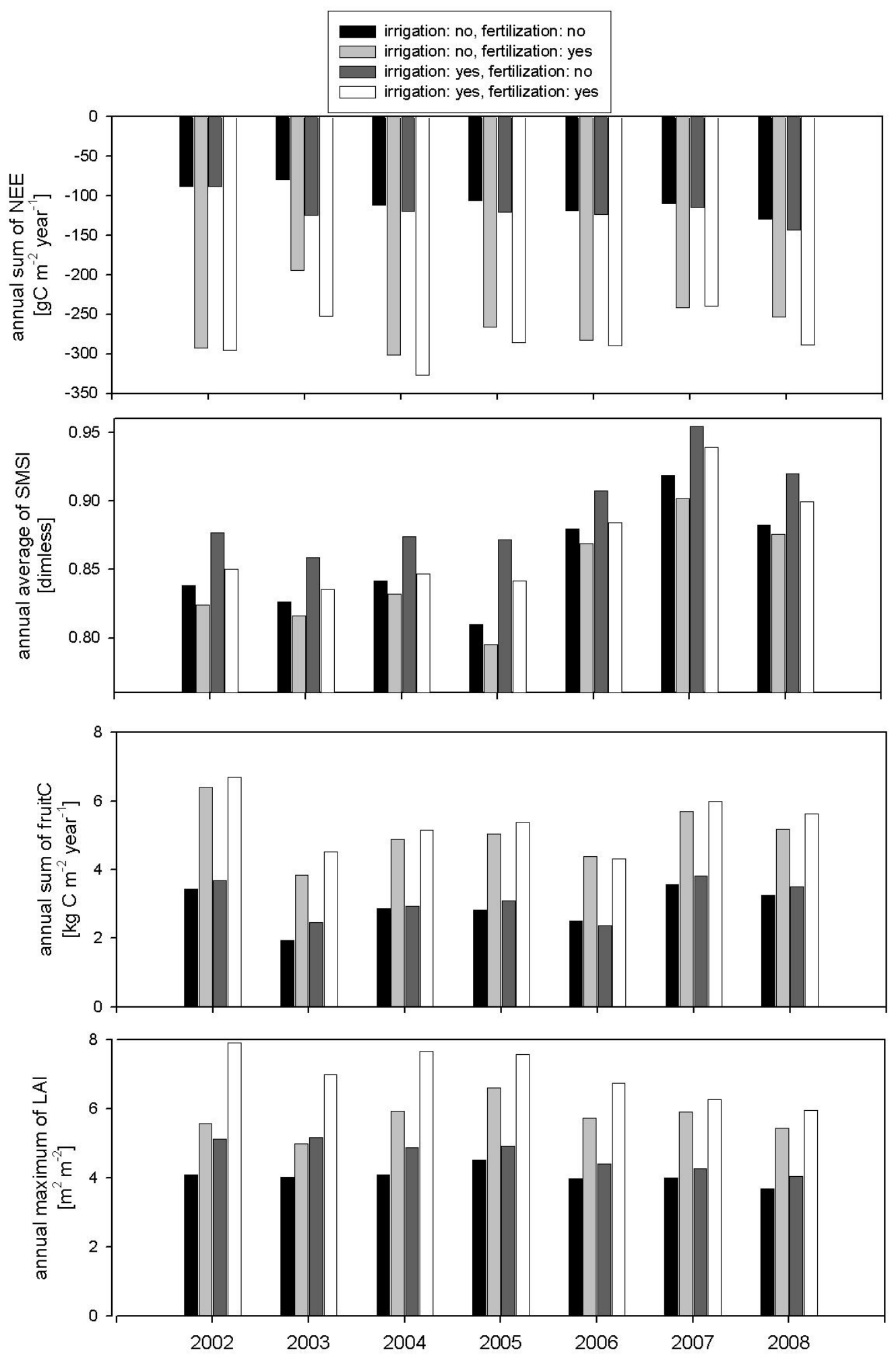

Figure S4: Simulated variables representing the management effect regarding Mead from 2002 to 2008. Black columns: irrigation - no, fertilization - no; light grey column: irrigation no, fertilization - yes; dark grey columns: irrigation - yes, fertilization - no; white columns: irrigation - yes, fertilization - yes. a) annual sum of NEE; b) annual average SMSI; c) annual sum of fruitC; d) annual maximum LAI. 


\section{S3.2 Case study on the genetically programmed leaf senescence}

We present a case study to demonstrate the effect of genetically programmed leaf senescence in case of maize. We examine the measured and simulated GPP, simulated SMSI, simulated carbon content of standing dead biomass and measured and simulated LAI for Mead in 2003. Simulation was initialized with grassland parameterization the same way as it was done for the previous case study.

Two simulation are compared: the first is without leaf senescence (the 'senescence mortality coefficient of aboveground plant material' parameter is zero) while the second is with senescence effect (the 'senescence mortality coefficient of aboveground plant material' parameter is in Table S1).

The figure shows that simulation of senescence effect decreases the overestimation of biomass and production: the RMSE of GPP simulation decreases from 3.8 to $3.4 \mathrm{gC} \mathrm{m}^{-2} \mathrm{day}^{-1}$, RMSE of LAI simulation decreases from 2.8 to $1.8 \mathrm{~m}^{2} \mathrm{~m}^{-2}, \mathrm{R}^{2}$ of GPP simulation increases from 0.85 to 0.88 and $\mathrm{R}^{2}$ of LAI simulation increases from 0.35 to 0.54 using senescence mortality simulation, respectively. 


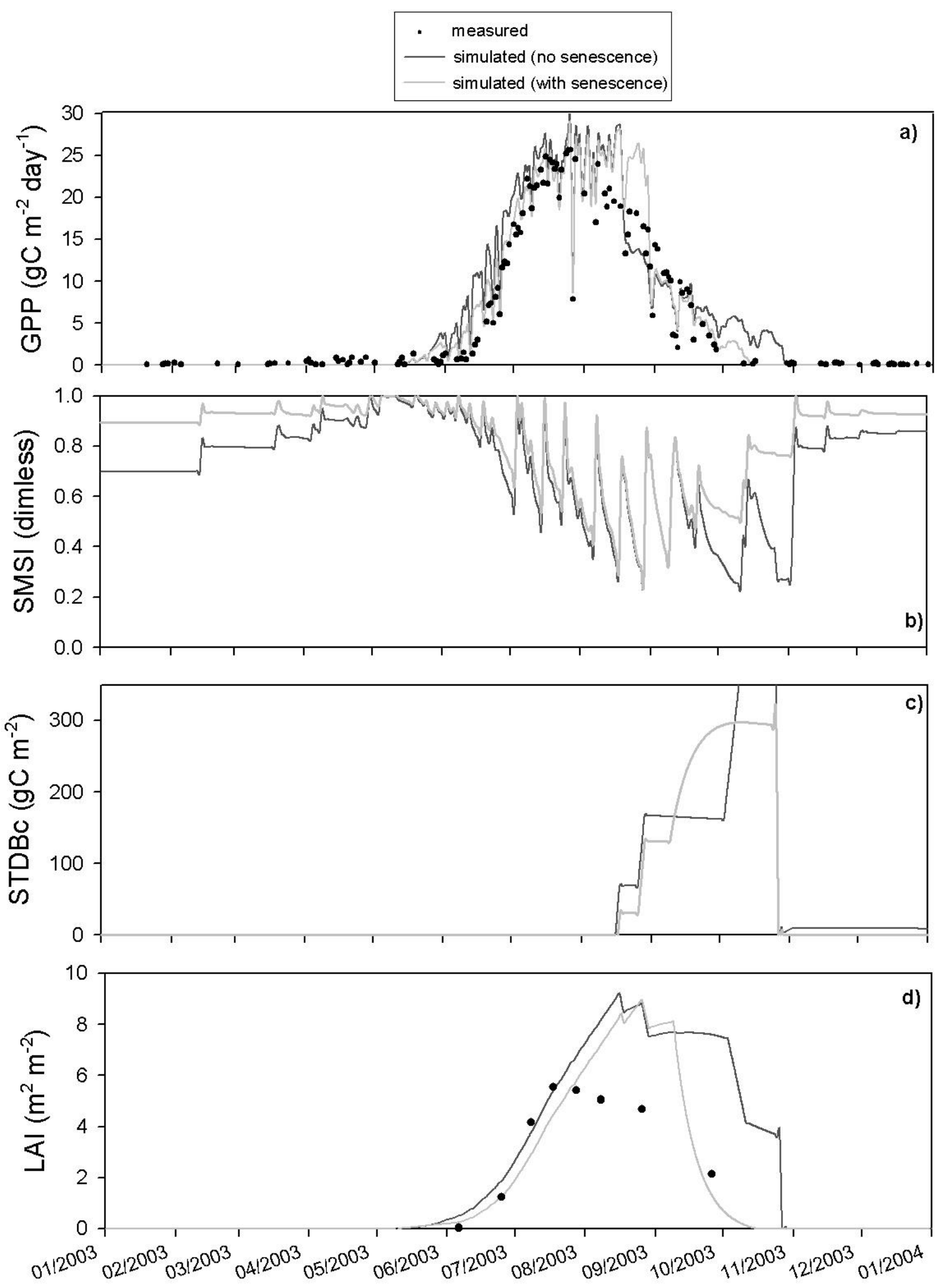

Figure S5: Measured (black dots) and simulated (light grey lines: without senescence; dark grey lines: with senescence) variables for 2003. a) GPP; b) SMSI; c) simulated carbon content of standing dead biomass; d) LAI. Black dots show the measurement data when available. 


\section{S4. Additional case studies for Jastrebarsko}

\section{S4.1 Case study on the combined effects of high groundwater level, presence of nitrogen-fixing tree species, and different denitrification rates for dry and wet soil on forest productivity}

Here we present case studies to demonstrate the following: a) effect of the use of groundwater level data on simulated soil water content; b) effect of the N-fixing species on GPP and LAI; c) effect of the setting different values for wet and dry bulk $\mathrm{N}$ denitrification proportions on the amount of soil mineralized nitrogen (SMINN); d) combined effects of groundwater level, presence of $\mathrm{N}$-fixing tree species and difference in dry and wet bulk $\mathrm{N}$ denitrification proportion on GPP and NPP in an average year.

Accordingly, a series of simulations was initialized, each starting with a spin-up run to reach a steady-state, followed by a normal run. Runs were made for combinations of: using or not using data on groundwater depth; using low $\left(0.0003 \mathrm{~kg} \mathrm{~N} \mathrm{~m}^{-2}\right.$ year $\left.^{-1}\right)$ or high $\left(0.0036 \mathrm{~kg} \mathrm{~N} \mathrm{~m}^{-2}\right.$ year $\left.^{-1}\right) \mathrm{N}$ fixation to simulate the lack of or the presence of symbiotic $\mathrm{N}$ fixation; using the same value (0.01) for both dry and wet bulk $\mathrm{N}$ denitrification proportions, or distinguishing between them (0.01 and 0.02 for dry and wet case, respectively). All other parameters of the model were kept unchanged in all simulations (see Table S1).

Effects of the use of groundwater level (GWT) data on the simulated soil water content (SWC) is shown in Fig. S6a. Depth to the groundwater was measured periodically, mostly in the vegetation season. In order to perform simulation, daily values for the groundwater level were needed. Daily values for soil groundwater level were obtained using linear interpolation corrected for measured soil water content and smoothed by moving average with 3 day window. Both simulations (with and without GWT) were run with the same set of parameters (Table S1). Most pronounced difference between the simulations is present during winter/spring period where the use of groundwater level data results with almost continuous saturation of the entire soil profile (Fig. S6b). This is in agreement with the records from field observation which indicate that the forest floor was partially covered with water until beginning of May 2009 and soil was completely saturated with water.

It is a well-known fact to foresters, and any other frequent visitors of lowland forests of Pedunculate oak, that in the wettest parts of forest (i.e. micro-depressions in relief), instead of oak, frequently group trees of Black alder. This is the case in Jastrebarsko forest as well. 
Since Black alder is $\mathrm{N}$-fixing species, we tested the effects of probable increase in $\mathrm{N}$ availability due to presence of symbiotic N fixation. According to Binkley et al. (1994) annual $\mathrm{N}$ fixation rate in pure Alder stands typically ranges between $0.01-0.02 \mathrm{~kg} \mathrm{~N} \mathrm{~m}^{-2}$ year ${ }^{-1}$. Taking into account the share of Black alder (24\% by wood volume; Marjanović et al., 2011), total $\mathrm{N}$ fixation rate (symbiotic and non-symbiotic) for Jastrebarsko forest site was estimated to be $0.0036 \mathrm{~kg} \mathrm{~N} \mathrm{~m}^{-2}$ year $^{-1}$ (Table S1).

Strong indication that symbiotic nitrogen fixing probably takes place is given by the results shown in Fig. S7. The simulation greatly underestimated measured GPP and LAI, probably due to overestimation of nitrogen limitation by the model (maximum LAI at Jastrebarsko is estimated to be $6.1 \mathrm{~m}^{2} \mathrm{~m}^{-2}$, see chapter 5.3 in the main paper). 

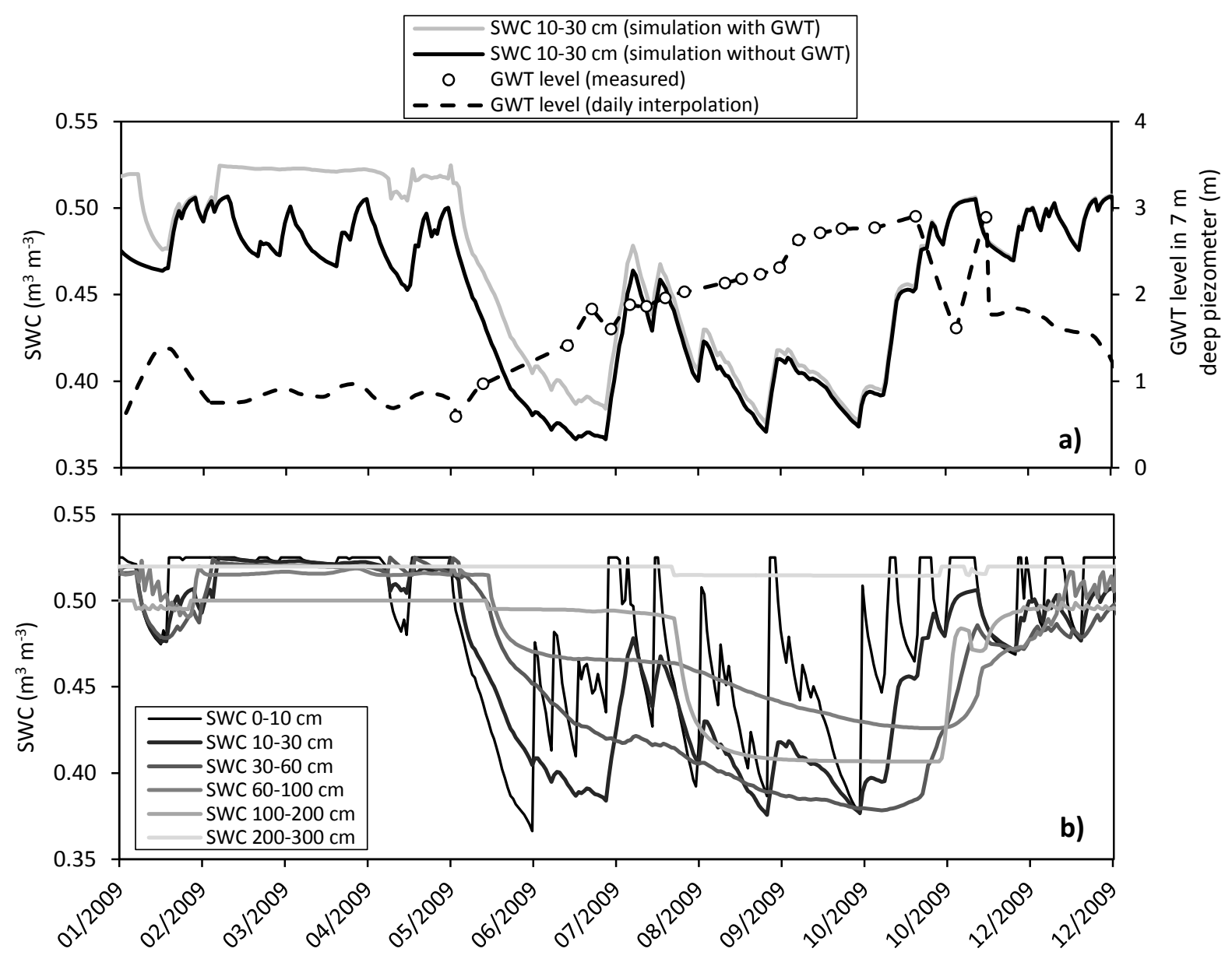

Figure S6: a) Effect of using groundwater level (GWT) data on simulated soil water content (SWC) in layer $1(10-30 \mathrm{~cm})$ during year 2009. Daily GWT values (dashed line) were obtained with linear interpolation from measured data (circles) or extrapolated with a model using measured SWC. b) Simulated soil water content for different soil layers during the year 2009 (GWT data used in simulation). 

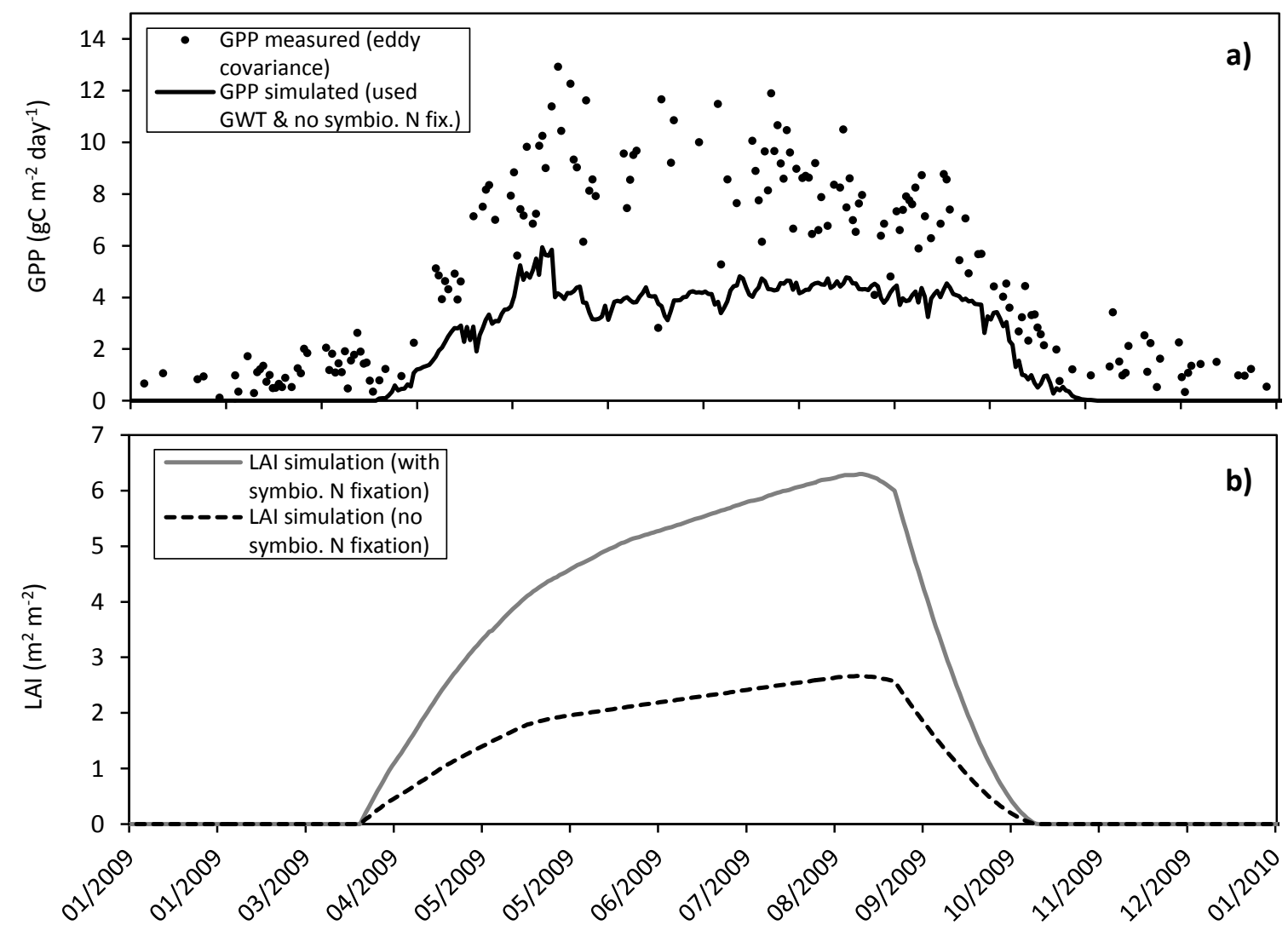

Figure S7: a) Simulated gross primary production when low $\mathrm{N}$ fixation rate $\left(0.0003 \mathrm{~kg} \mathrm{~N} \mathrm{~m}^{-2}\right.$ year $\left.^{-1}\right)$ was used instead of the proposed one (Table S1), which would occur if $\mathrm{N}$-fixing species would not be present. b) Leaf area index simulated with and without symbiotic N fixation (GWT data, and proposed set of parameters was used for simulation; see Table S1). 
Mineralization of soil organic matter depends on oxygen availability, which is strongly correlated with the soil water content. Effects of bulk denitrification proportion parameters (wet and dry) on the soil mineralized nitrogen, in combination with soil water content, are shown in Fig. S8. Higher denitrification in wet conditions negatively reflects on SMINN due higher denitrification rate (wet>dry). This is further pronounced when GWT data is used in simulation because GWT increases SWC (i.e. soil wetness; compare Fig. S6). This is an example of how $\mathrm{N}$ availability decreases when soil wetness becomes very high. It also emphasized the competitive advantage that $\mathrm{N}$-fixing species have for growth at locations where prolonged soil waterlogging occurs, compared to other non $\mathrm{N}$-fixing species.

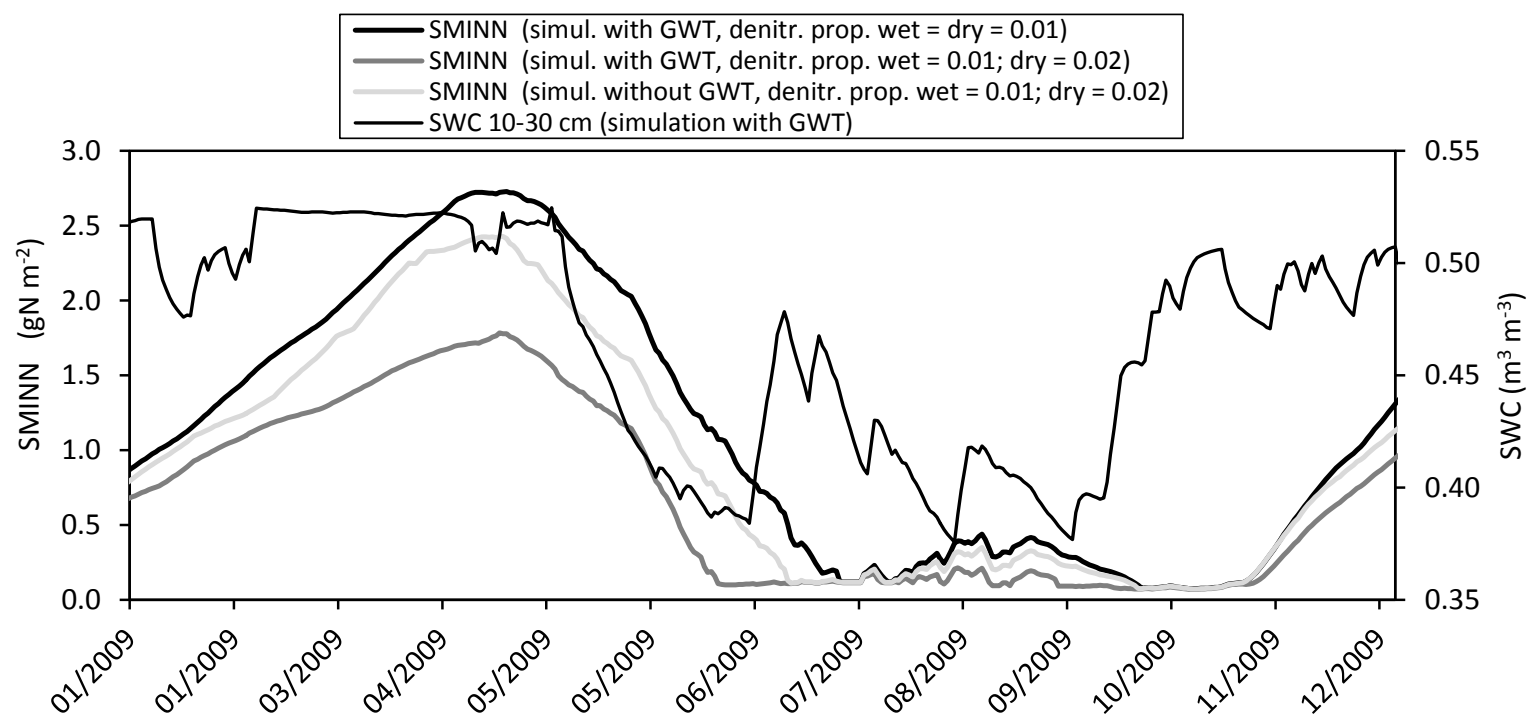

Figure S8: Effects of the setting different values for wet and dry bulk $\mathrm{N}$ denitrification proportions in simulation on soil mineralized nitrogen (SMINN). Note: When GWT data is not used in simulation, SMINN goes up (lightest gray) compared to the case when GWT is used (dark gray), which is a consequence of higher simulated SWC (see Fig. S6). 
Finally, we assessed the interconnection between effects on gross and net primary production (NPP) of groundwater level (via soil water content), presence of $\mathrm{N}$-fixing tree species, and difference in rates of denitrification in wet and dry soil conditions (Fig. S9). Apparently, the highest influence on the forest productivity has the presence of $\mathrm{N}$-fixing tree species. However, denitrification in conditions with high SWC (wet conditions) also plays significant role. Information on the groundwater level can significantly affect the SWC simulation, i.e. in lowland ecosystems we should not assume that SWC is driven only by precipitation, runoff, evapotranspiration, and leaching.

Although calibration and validation of the Biome-BGCMuSo model is pending, this case study shows us high value of newly implemented model features, which enable simulation of complex processes in forest ecosystem such as lowland forest of Pedunculate oak. 


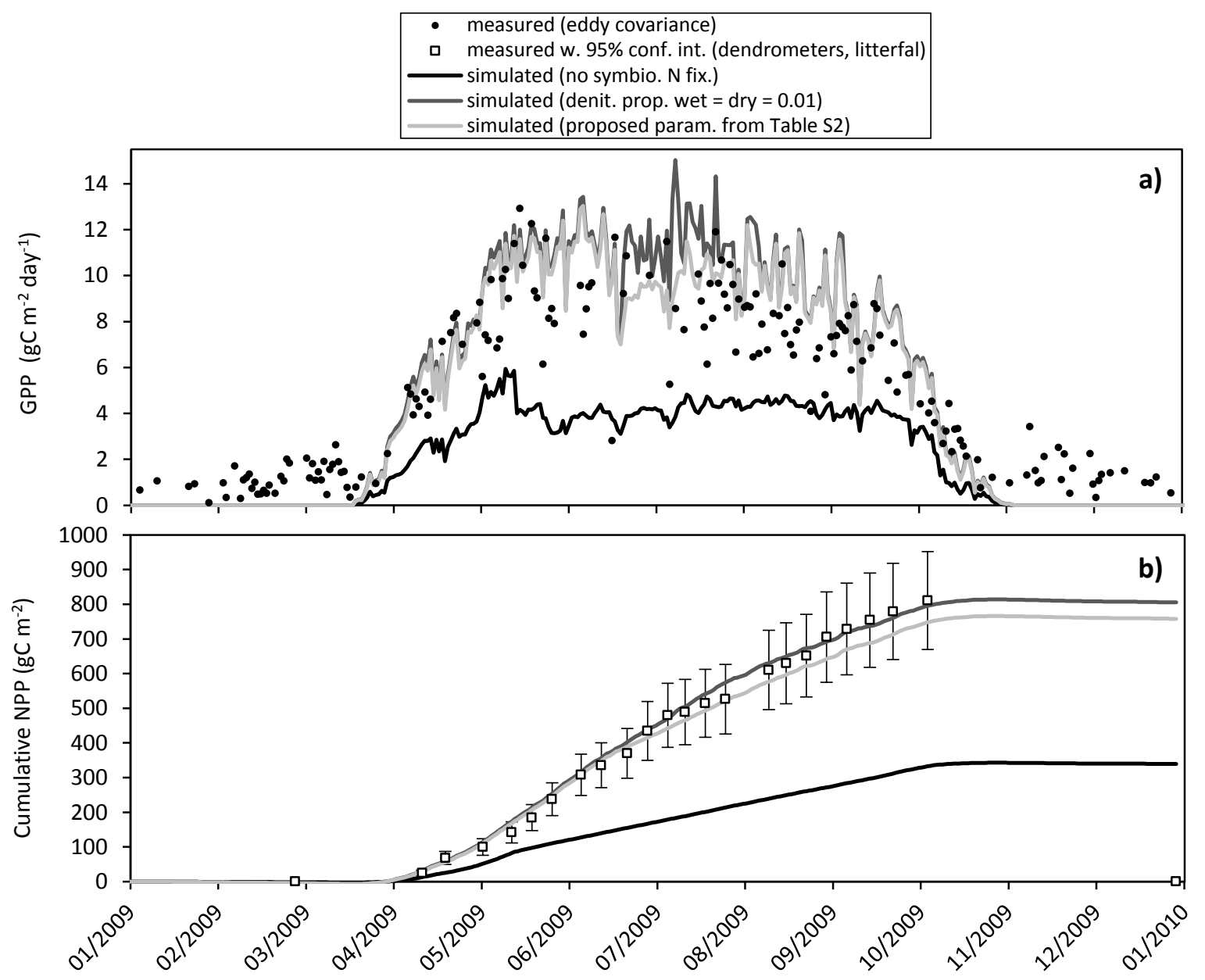

Figure S9: a) Overview of simulated Gross Primary Production and; b) cumulative Net Primary Production, assuming no symbiotic N fixation (black), equal wet and dry bulk $\mathrm{N}$ denitrification proportion (dark gray) and using different wet and dry bulk $\mathrm{N}$ denitrification proportion parameters from Table S2 (light gray). In all simulations GWT level data were used. 


\section{References}

Binkley, D., Cromack, K.Jr., Baker, D.D.: Nitrogen Fixation by Red Alder: Biology, Rates, and Controls. In: Hibbs, D.E., DeBell, D.S., Tarrant, R.F. (Eds.), The Biology and Management of Red Alder. Oregon State University Press, Corvallis. Or., xi, 256 pp. 1994

Cannell, M. G. R., Thornley, J. H. M.: Modelling the Components of Plant Respiration: Some Guiding Principles, Annals of Botany 85, 45-54, doi: 10.1006/anbo.1999.0997, 2000

Fodor, N., Pásztor, L. and Németh, T.: Coupling the 4M crop model with national geo-databases for assessing the effects of climate change on agro-ecological characteristics of Hungary, Int. J. Digit. Earth, 7, 391-410, doi:10.1080/17538947.2012.689998, 2014

Gervois, S., de Noblet-Ducoudré, N., Viovy, N., Ciais, P., Brisson, N., Seguin, B. and Perrier, A.: Including croplands in a global biosphere model: Methodology and evaluation at specific sites, Earth Interact., 8, 1-25, doi:10.1175/1087-3562(2004)8<1:ICIAGB>2.0.CO;2, 2004.

Golinkoff, J. S.: Estimation and Modeling of Forest Attributes Across Large Spatial Scales Using BiomeBGC, High-Resolution Imagery, Lidar Data, And Inventory Data. The University of Montana. Theses, Dissertations, Professional Papers. Paper 384, 2013.

Gordon, W. S., Jackson, R. B.: Nutrient Concentrations in Fine Roots, Ecology, 81, 275-280, 2000.

Hidy, D., Barcza, Z., Haszpra, L., Churkina, G., Pintér, K. and Nagy, Z.: Development of the Biome-BGC model for simulation of managed herbaceous ecosystems, Ecol. Modell., 226, 99-119, doi:10.1016/j.ecolmodel.2011.11.008, 2012.

Jarvis, N. J.: A simple empirical model of root water uptake, J. Hydrol., 107, 57-72, doi:10.1016/00221694(89)90050-4, 1989.

Marjanović, H., Ostrogović, M. Z., Alberti, G., Balenović, I., Paladinić, E., Indir, K., Peresotti, A., Vuletić, D.: Carbon dynamics in younger stands of pedunculate oak during two vegetation periods, Šumarski list (special issue), 135, 59-73, 2011

Nagy, Z., Barcza, Z., Horváth, L., Balogh, J., Hagyó, A., Káposztás, N., Grosz, B., Machon, A. and Pintér, K.: Measurements and estimations of biosphere-atmosphere exchange of greenhouse gases - Grasslands, in Atmospheric Greenhouse Gases: The Hungarian Perspective, edited by L. Haszpra, pp. 91-120, Springer, Dordrecht - Heidelberg - London - New York., 2010.

Oleson, K. W., Lawrence, D. M., Bonan, G. B., Drewniak, B., Huang, M., Koven, C. D., Levis, S., Li, F., Riley, W. J., Subin, Z. M., Swenson, S. C., Thornton, P. E., Bozbiyik, A., Fisher, R., Heald, C. L., Kluzek, E., Lamarque, J.- F., Lawrence, P. J., Leung, R., Lipscomb, W. Muszala, S., Ricciuto, D. M., Sacks, W., Sun, Y., Tang, J. and Yang, Z.- L.: Technical Description of version 4.5 of the Community Land Model (CLM). NCAR Technical Note, NCAR/TN-503+STR, 434p. ISSN Electronic Edition 2153-2400, 2013.

Ostrogović, M. Z.: Carbon stocks and carbon balance of an even-aged pedunculate oak (Quercus robur L.) forest in Kupa river basin, doctoral thesis, Faculty of forestry, University of Zagreb, 2013. (in Croatian with English summary)

Pietsch, S. A., Hasenauer, H., Thornton, P. E.: BGC-model parameters for tree species growing in central European forests, Forest Ecology and Management, 211, 264-295, 2005

Seletković, I.: Dynamics of biogenic elements in natural stands and forest cultures of pedunculate oak (Quercus robur L.), Rad. Sumar. inst., 38, 65-96, Jastrebarsko, 2003. (in Croatian with English summary)

Toscano, G., Cimino, G.: New carbon from low cost vegetal precursors: acorn and cypress con, Cent. Eur. J. Chem., 11(12), 2012-2021, doi: 10.2478/s11532-013-0333-1, 2013. 
White, M., Thornton, P. E., Running, S. W. and Nemani, R. R.: Parameterization and sensitivity analysis of the BIOME-BGC terrestrial ecosystem model: Net primary production controls, Earth Interact., 4, 1-85, doi:10.1175/1087-3562(2000)004<0003:PASAOT>2.0.CO;2, 2000.

Zadworny, M., McCormack, M. L., Rawlik, K. and Jagodzinski, A. M:. Seasonal variation in chemistry, but not morphology, in roots of Quercus robur growing in different soil types. Tree Physiology 35, 644-652, doi:10.1093/treephys/tpv018, 2015. 